\title{
EFFECT OF POLYETHYLENE BLACK PLASTIC MULCH ON GROWTH AND YIELD OF TWO SUMMER VEGETABLE CROPS UNDER RAIN-FED CONDITIONS UNDER SEMI-ARID REGION CONDITIONS
}

\author{
Atif Y. Mahadeen \\ Department of Plant Production, Faculty of Agriculture, Mu'tah University, P.O. Box 7, Karak, Jordan
}

Received 2014-01-07; Revised 2014-01-08; Accepted 2014-01-29

\begin{abstract}
Water use efficiency in agriculture can be enhanced by several strategies mainly by reducing evaporation from the soil surface. The mulching techniques were being used widely in irrigated crop production worldwide. The mulching techniques can be also implemented in summer vegetables production under rain-fed conditions. The current study aimed at evaluating the effect of polyethylene black plastic mulch on growth and yield of okra, Abelmoschus esculentus and summer squash, Cucurbita pepo L. under rain-fed conditions of Jordan. Two field experiments were conducted during summer growing season at Al-Rabbah Agricultural Research Station, Mu'tah University, Jordan. Soil cover treatments were polyethylene black plastic mulch and no mulch (bare soil). The results indicated that the mulched plots had higher soil moisture content than bare soil plots, which has positively reflected on vegetative and yield parameters. Using polyethylene plastic mulch had pronounced positive effect on yield of okra and squash as compared to bare soil. Early, middle, late and total yield of both vegetable crops were significantly increased in plots covered with plastic mulch. In addition, fruit number and weight had also an increasing trend as fruit yield. Plots covered with black plastic mulch were produced higher fresh and dry weights of both vegetable crops. It ban be concluded that using black plastic mulch as a soil cover increased okra and squash vegetative growth and yield under rain-fed conditions.
\end{abstract}

Keywords: Okra, Squash, Plastic Mulch, Growth, Yield, Rain-Fed Conditions

\section{INTRODUCTION}

Water deficit is one of the most environmental stresses that affecting agricultural productivity in much of the world and may result in considerable growth and yield reductions. However, Jordan ranks as the world's fourth poorest country in terms of water resources. Rain-fed lands make up $75 \%$ of the arable lands, while the remaining $25 \%$ is partially or entirely irrigated and lies mostly in the Jordan Valley and highlands of the country. In the rain-fed areas of Jordan, the mean annual precipitation ranges between 250 and $350 \mathrm{~mm}$. In these areas, soil moisture is generally limited and crop growth is stressed by drought during summer growing season, resulting in decreased and unsustainable crop yields. Rain falls occur mainly during the winter season, so that summer vegetables should usually rely on stored soil moisture.

Water use efficiency of dry matter production can be increased in different ways but chiefly by decreasing evaporation from the soil surface. In Jordan, the use of polyethylene mulch is a common and popular cultural practice in vegetables' production under irrigated conditions; while it is uncommon under rain-fed conditions. This technique may also be introduced in the production of summer vegetables under rain-fed conditions. Squash, Cucurbita pepo and okra, Abelmoschus esculentus are common summer vegetables' crops that mainly planted in rural regions of semi-arid areas under rain-fed conditions. Black 
polyethylene plastic mulch is the standard plastic mulch used in vegetable production in Jordan. Worldwide, the increase usage of polyethylene mulch is due to its benefits when applied in the field, i.e. increases soil temperature, especially in early spring, reduces weed problems, enhances moisture conservation, increases crop yields and leads to more efficient use of soil nutrients (Kwabiah, 2004; Ban et al., 2009; Mamkagh, 2009; Berihun, 2011; Bhatt et al., 2011; Hatami et al., 2012; Kumar and Lal, 2012).

The use of polyethylene mulch has been reported to conserve soil moisture (Bhagat and Acharya, 1987; Anikwe et al., 2007; Kumar and Lal, 2012). Hence, under prevailing drought and water scarcity conditions as in semi-arid regions of Jordan, conservation of soil moisture and ensuring its availability to agricultural crops are of vital importance. In addition to the positive role of black polyethylene mulch in soil moisture conservation, it inhabits weeds growth as an extra benefits (Anikwe et al., 2007; Mamkagh, 2009; Hatami et al., 2012; Kumar and Lal, 2012; Singh and Kamal, 2012).

Unfortunately, according to our knowledge, there is inadequate research work published on black plastic mulch under rain-fed conditions, which might help growers to resolve water deficit problems in semi-arid regions. Generally, researchers using black plastic instead of bare soil have recorded higher yield of many crops (Ibarra et al., 2001; Kwabiah, 2004; Ban et al., 2009; Igbal et al., 2009; Mamkagh, 2009; Moreno et al., 2009; Rashidi et al., 2010; Berihun, 2011; Bhatt et al., 2011; Hatami et al., 2012; Kumar and Lal, 2012). Nevertheless, the current study aimed to investigate the effect of black polyethylene plastic mulch on okra and squash growth and yield under rain-fed conditions.

\section{MATERIALS AND METHODS}

\subsection{Experimental Site}

Two field experiments were conducted at AlRabbah Agricultural Research Station, Faculty of Agriculture, Mutah University, Jordan during the 2010 summer growing season. The region has a Mediterranean climate characterized by semi-arid, a cold rainy winter and a hot dry summer. The region has an annual mean rainfall of $350 \mathrm{~mm}$, where the most of rains occur from December to February. The soil of the experimental field is loamy sand with $\mathrm{pH}$ 7.9, EC $1.59 \mathrm{dS} \mathrm{m} \mathrm{m}^{-1}$, organic matter $1.69 \%, \mathrm{CaCO}_{3}$ $30 \%$, total $\mathrm{N}$ of $0.061 \%$ and available $\mathrm{P}$ of $22 \mathrm{ppm}$.

\subsection{Experimental Design and Treatments}

The experiments were laid out in a Randomized Complete Block Design (RCBD) with in triplicates. Two treatments; Black Polyethylene plastic mulch (BP Mulch) and non-mulched were used. Each plot consisted of 6 rows, each of $2.4 \mathrm{~m}$ long. The inter- and intra-row spacing was $1.0 \mathrm{~m}$ and $0.4 \mathrm{~m}$, respectively. The measurements were taken from the middle 4 rows. The land was ploughed using a disc-harrowed two times on December and early April. Then, the beds were manually prepared with traditional hoes. The black plastic-film (100 cm in width and $125 \mu$ thick) was used to cover the experimental beds before planting (Mid April) and two sides of the film were held down with soil. Squash (Anita Hybrid) and okra (Clemson Spineless) seeds were sown on April 15, 2010.

\subsection{Data Collection}

Soil moisture content was measured three times at 30-day-interval (30, 60 and 90 days after planting) up to $30 \mathrm{~cm}$ soil depth by a gravimetric method (Black, 1965). The soil from 0-30 cm depth was taken by a manual coring. Gravimetric moisture content $\left(\mathrm{g} \mathrm{g}^{-1}\right)$ of the soil samples was calculated on oven dry weight basis, then converted into volumetric moisture content $\left(\mathrm{cm}^{3} \mathrm{~cm}^{-3}\right)$ and hereafter expressed as profile water content in 0-30 cm soil depth. The seedling emergence was recorded from the date of planting until $50 \%$ cotyledons emergence above the soil surface. Flowering time was recorded when $50 \%$ of the plant started flowering. For fresh and dry weights, 4 plants were randomly selected, tagged and sampled. Length of okra plant and number of branches were taken from 4 sampled plants. Fruits of each crop were harvested at the immature stage, counted and weighed. Fruit yield was separated into: Early, middle and late yields as well as fruit number was recorded. Squash was harvested from 31st May to 19th July, 2010 and okra was harvested from 21st July to 20th September, 2010.

\subsection{Statistical Analysis}

Analysis of data was performed using the statistical package MSTAT-C (Michigan State University). Onefactor-Analysis of Variance (ANOVA) was conducted to find the significant differences among the means (Wilkinson, 1990). The level of significant was calculated at $\mathrm{p} \leq 0.05$ using the Least Significant Differences (LSD) test (Clewer and Scarisbrick, 2001). 


\section{RESULTS}

\subsection{Soil Moisture Content}

The results of the present study indicated that Soil Moisture Content (SMC) is greatly retained under the polyethylene plastic mulch (Table 1). The non-mulched plots had lower soil moisture content than polyethylene black plastic mulched plots. Higher soil moisture content was observed at 30,60 and 90 days after planting in plots covered with black plastic mulch as compared to non mulched plots (bare soil). But, soil moisture content at 90 days after planting was not affected by black plastic mulch treatment in case of squash crop. This means that black plastic mulch reduced soil water evaporation and thus, helps retain soil water.

\subsection{Vegetative Growth Parameters}

Seedlings emergence of both summer vegetable crops tested (okra and squash) was significantly earlier in mulched plots as compared to bare soil (Table 2). The earliness in germination time was about 4 and 3 days for okra and squash, respectively. In addition, flowering time of both vegetable crops was affected by using black plastic mulch (Table 2). Okra and squash plants reached 50\% flowering about 4 and 6 days earlier as compared to the non-mulched plots. Vegetative growth parameters of okra and squash were significantly increased by using black plastic mulch as compared to bare soil (Table 2). Fresh and dry weights of both crops at the end of the growing season were significantly higher when the soil surface was covered with black plastic mulch (Table 2). The percent increased in fresh and dry weights was $68 \%$ and $65 \%$, for okra as well as 76 and $63 \%$ for squash, respectively. Length of okra plants and number of branches per plant were significantly higher when black plastic mulch used as compared to non-mulched treatment (Table 2).

\subsection{Yield and its Distribution}

The effect of polyethylene mulch on okra and squash yields and their distribution (early, middle and late as well as total yield) are presented in Table 3 . Early, middle and late yields of both vegetable crops were significantly higher when soil was covered with black plastic mulch as compared to bare soil. The same trend was also observed for early, middle, late and total fruit number (Table 4). The increased percentage in total yield of okra and squash was about $140 \%$ and $61 \%$, respectively as compared to control (bare soil). Generally, using black plastic mulch induced earliness of productivity of both vegetable crops; for instance, the early okra yield $\left(2.85\right.$ ton $\left.^{- \text {ha }}\right)$ in mulched plots was equal to total yield $\left(2.82\right.$ ton $\left.^{\text {-ha }}\right)$ in non-mulched plots. Average fruit weight of okra was not significantly affected by using polyethylene mulch (Table 5), however, average fruit weight tended to increase by using plastic mulch. On the other hand, squash average fruit weight of early, meddle and late yield was significantly increased by using black plastic mulch.

Table 1. Effects of polyethylene black plastic mulch on soil moisture content grown with okra and squash under rain-fed conditions

Soil Moisture Content (SMC)

\begin{tabular}{llcc}
\hline & \multicolumn{2}{l}{ Soil Moisture Content (SMC) } \\
& - & \\
Treatment & (30 days) & $(60$ days $)$ & (90 days) \\
\hline Okra & & & \\
BP Mulch & $27.0 \mathrm{a}^{*}$ & $18.1 \mathrm{a}$ & $14.6 \mathrm{a}$ \\
No mulch & $22.9 \mathrm{~b}$ & $15.5 \mathrm{~b}$ & $12.4 \mathrm{~b}$ \\
Squash & & & \\
BP mulch & $25.7 \mathrm{a}$ & $16.3 \mathrm{a}$ & $12.6 \mathrm{a}$ \\
No mulch & $20.2 \mathrm{~b}$ & $13.0 \mathrm{~b}$ & $11.8 \mathrm{a}$ \\
\hline
\end{tabular}

*Means having different letters within each column and crop are significantly different at $5 \%$ level

Table 2. Effects of polyethylene black plastic mulch on vegetative growth, seedling emergence and flowering times of okra and squash grown under rain-fed conditions

\begin{tabular}{|c|c|c|c|c|c|c|}
\hline Treatment & $\begin{array}{l}\text { Seedling } \\
\text { emergence (days) }\end{array}$ & $\begin{array}{l}\text { Flowering } \\
\text { time (days) }\end{array}$ & $\begin{array}{l}\text { Plant } \\
\text { length }(\mathrm{cm})\end{array}$ & $\begin{array}{l}\text { Branch } \\
\text { no. }\end{array}$ & $\begin{array}{l}\text { Fresh wt } \\
\text { (g/plant) }\end{array}$ & $\begin{array}{l}\text { Dry wt } \\
\text { (g/plant) }\end{array}$ \\
\hline \multicolumn{7}{|l|}{ Okra } \\
\hline BP Mulch & $15.44 a^{*}$ & $44.4 \mathrm{a}$ & $87.9 a$ & $14.9 \mathrm{a}$ & $255.6 \mathrm{a}$ & $58.6 \mathrm{a}$ \\
\hline No mulch & $19.00 \mathrm{~b}$ & $48.0 \mathrm{~b}$ & $68.4 b$ & $11.4 \mathrm{~b}$ & $152.1 \mathrm{~b}$ & $35.6 \mathrm{~b}$ \\
\hline \multicolumn{7}{|l|}{ Squash } \\
\hline BP Mulch & $11.00 \mathrm{a}$ & $35.0 \mathrm{a}$ & n.d d* $^{*}$ & n.d & $626.2 \mathrm{a}$ & $96.7 \mathrm{a}$ \\
\hline No mulch & $13.90 \mathrm{~b}$ & $38.4 \mathrm{~b}$ & n.d & n.d & $356.3 \mathrm{~b}$ & $59.0 \mathrm{~b}$ \\
\hline
\end{tabular}

*Means having different letters within each column and crop are significantly different at $5 \%$ level of probability ** n.d: Not determine 
Atif Y. Mahadeen / American Journal of Agricultural and Biological Sciences 9 (2): 202-207, 2014

Table 3. Effect of polyethylene black plastic mulch on yield of okra and squash grown under rain-fed conditions

\begin{tabular}{|c|c|c|c|c|}
\hline \multirow[b]{2}{*}{ Treatment } & \multicolumn{4}{|c|}{ Yield distribution (ton/ha) } \\
\hline & Early & Med & Late & Total \\
\hline \multicolumn{5}{|l|}{ Okra } \\
\hline BP Mulch & $2.846 \mathrm{a}^{*}$ & $2.945 \mathrm{a}$ & $0.968 \mathrm{a}$ & $6.759 a$ \\
\hline No mulch & $0.956 b$ & $1.421 \mathrm{~b}$ & $0.445 b$ & $2.822 b$ \\
\hline \multicolumn{5}{|l|}{ Squash } \\
\hline BP Mulch & $9.620 \mathrm{a}$ & $10.500 \mathrm{a}$ & $5.550 \mathrm{a}$ & $25.670 \mathrm{a}$ \\
\hline No mulch & $5.880 \mathrm{~b}$ & $7.320 \mathrm{~b}$ & $2.700 \mathrm{~b}$ & $15.900 \mathrm{~b}$ \\
\hline
\end{tabular}

*Means having different letters within each column are significantly different at $5 \%$ level of probability

Table 4. Effects of polyethylene black plastic mulch on fruit number of okra and squash grown under rain-fed conditions

\begin{tabular}{|c|c|c|c|c|}
\hline \multirow[b]{2}{*}{ Treatment } & \multicolumn{4}{|c|}{ Fruit number $\left(1000 \mathrm{ha}^{-1}\right)$} \\
\hline & Early & Med & Late & Total \\
\hline \multicolumn{5}{|l|}{ Okra } \\
\hline BP mulch & $427.8 \mathrm{a} *$ & $472.4 \mathrm{a}$ & $171.3 \mathrm{a}$ & $1071.5 \mathrm{a}$ \\
\hline No Mulch & $146.6 b$ & $236.3 b$ & $88.6 \mathrm{~b}$ & $471.5 b$ \\
\hline \multicolumn{5}{|l|}{ Squash } \\
\hline BP Mulch & $72.9 a$ & $111.7 \mathrm{a}$ & $65.6 \mathrm{a}$ & $250.2 \mathrm{a}$ \\
\hline No mulch & $50.9 \mathrm{~b}$ & $101.6 \mathrm{~b}$ & $38.7 \mathrm{~b}$ & $191.2 b$ \\
\hline
\end{tabular}

*Means having different letters within each column and crop are significantly different at 5\% level of probability

Table 5. Effects of polyethylene black plastic mulch on average fruit weight of okra and squash grown under rain-fed conditions

\begin{tabular}{|c|c|c|c|c|}
\hline \multirow[b]{2}{*}{ Treatment } & \multicolumn{4}{|c|}{ Average fruit weight $(\mathrm{g})$} \\
\hline & Early & Med & Late & Total \\
\hline \multicolumn{5}{|l|}{ Okra } \\
\hline BP mulch & $6.652 \mathrm{a}^{*}$ & $6.234 \mathrm{a}$ & $5.652 \mathrm{a}$ & $6.307 \mathrm{a}$ \\
\hline No Mulch & $6.521 \mathrm{a}$ & $6.012 \mathrm{a}$ & $5.021 \mathrm{a}$ & $5.985 \mathrm{a}$ \\
\hline \multicolumn{5}{|l|}{ Squash } \\
\hline BP Mulch & $132.200 \mathrm{a}$ & $93.900 \mathrm{a}$ & $84.600 \mathrm{a}$ & $102.600 \mathrm{a}$ \\
\hline No mulch & $115.500 \mathrm{~b}$ & $72.000 \mathrm{~b}$ & $69.700 \mathrm{~b}$ & $83.120 b$ \\
\hline
\end{tabular}

\section{DISCUSSION}

The use of plastic mulch helps conserving water by reducing evaporation from soil surface, controlling weed growth and reducing soil compaction. According to Ramakrishna et al. (2006) evaporation from the soil accounts for $25-50 \%$ of the total quantity of water used. The results of this study were in line with the findings of Abu-Goukh and El-Balla (2003); Ramakrishna et al. (2006); Ban et al. (2009); Wang et al. (2009) and Kumar and Lal (2012), in which they indicated that the main advantage of using plastic mulch is to retain soil moisture. Ramakrishna et al. (2006) reported that the important practice for rain-fed agriculture is to decrease evaporation of soil water. Mulch prevents soil water evaporation and thus helps retaining soil moisture.
Vegetative growth improvement might be explained in view that plastic mulches improve moisture conservation and availability, which ultimately leads to improve plant growth. This could be explained in view of soil temperature and moisture as previously reported by Abu-Goukh and El-Balla (2003); Ban et al. (2009 and Mamkagh (2009). Earlier researchers indicated that improvement in growth characters as a result of using mulches might be due to the enhancement in photosynthesis and other metabolic activities (Bhatt et al., 2011; Parmar et al., 2013). Higher soil moisture content and soil temperature under plastic mulch improve the plant microclimate leading to early growth and development, which advances the flowering. Similar kind of observations with respect to plant growth parameters were also reported by Igbal et al. (2009) in hot pepper, Singh and Kamal (2012) in tomato and 
Parmar et al. (2013) in watermelon. Parmar et al. (2013) reported that the increase in growth parameters of watermelon is attributed to sufficient soil moisture near root zone and minimized the evaporation loss due to mulching. The extended retention of moisture and availability of moisture also lead to higher uptake of nutrients for plants' proper growth and development, resulted in higher growth of plant as compared to bare soil.

Higher yield production of both investigated vegetable crops resulted from the application of polyethylene plastic mulch might be due to sufficient soil moisture near the root zone that ensures better plant growth as expressed in vigorous plant growth during early and mid season. Also, this might be due to earlier seedling emergence and earlier flowering that induced enhancement of early and med yields of both vegetable crops. The results of the present study agreed with the finding of Abdul-Baki and Spence (1992); Igbal et al. (2009); Wang et al. (2009); Rashidi et al. (2010) and Parmar et al. (2013). These researchers indicated that plants under polyethylene mulch produce larger fruit and have higher fruit yield per plant because of the better plant growth that due to favorable hydro-thermal regime of soil and complete weed free environment. Furthermore, they mentioned that the extended retention of moisture and availability of moisture also lead to a higher uptake of nutrient for proper growth and development of plants, resulted in higher growth of plant as compared to control.

Higher soil moisture content increases root proliferation and thus enhances availability of nutrients to crop roots (Sharma et al., 1990; Ogban et al., 2008; Mamkagh, 2009). These figures also imply that greater moisture availability due to mulched crop during the growing season helps to cope better with drought in mid and late season drought. Mulching the soil surface favorably influences the soil moisture regime by controlling evaporation from the soil surface (Pawar et al., 2004; Mamkagh, 2009; Wang et al., 2009) and facilitates condensation of soil water at night due to temperature reversals (Tisdall et al., 1991).

\section{CONCLUSION}

The results of this study exhibited the significant effect of black polyethylene plastic mulch on soil moisture content during the growing season. The soil moisture content was higher under the mulched than the non-mulched treatment. The black plastic mulch reduced soil water evaporation and improve soil water retention. Moreover, using polyethylene plastic mulch produced earlier seedling emergence, more vigorous plant, earlier and higher yield as compared to non-mulched treatment. Under rain-fed conditions of semi-arid regions, it is recommended to use polyethylene black plastic mulch as soil mulching to enhance growth and yield of summer vegetables. Further studies are being needed to investigate the effect of different mulching types and colors under rain-fed conditions.

\section{REFERENCES}

Abdul-Baki, A. and C. Spence, 1992. Black polyethylene mulch doubled yield of fresh-market field tomatoes. Hort. Sci., 27: 787-789.

Abu-Goukh, A.B.A. and M.M.A. El-Balla, 2003. Use of plastic mulch for better performance and yield of okra during winter in Sudan. K. J. Agric. Sci., 11: 165-178.

Anikwe, M.A.N., C.N. Mbah, P.I. Ezeaku and V.N. Onyia, 2007. Tillage and plastic mulch effects on soil properties and growth and yield of cocoyam (Colocasia esculenta) on an ultisol in Southeastern Nigeria. Soil Till. Res., 93: 264-272. DOI: 10.1016/j.still.2006.04.007

Ban, D., K. Zanic, G. Dumicic, T.G. Culjak and S.G. Ban, 2009. The type of polyethylene mulch impacts vegetative growth, yield and aphid populations in watermelon production. J. Food Agric. Environ., 7: 543-550.

Berihun, B., 2011. Effect of mulching and amount of water on the yield of tomato under drip irrigation. J. Hort. Forest., 3: 200-206.

Bhagat, R.M. and C.L. Acharya, 1987. Effect of soil management on rain-fed wheat in Northern India. I. Hydro-thermal regime and root growth. Soil Till. Res., 9: 65-77. DOI: 10.1016/0167-1987(87)90051-1

Bhatt, L., R. Rana, S.P. Uniyal and V.P Singh, 2011. Effect of mulch materials on vegetative characters, yield and economics of summer squash (Cucurbita реро) under rainfed mid-hill condition of Uttarakhand. Veg. Sci., 38: 165-168.

Black, C.A., 1965. Methods of soil Analysis. 1st Edn., American Society of Agronomy, Madison, pp: 1572.

Clewer, A.G. and D.H. Scarisbrick, 2001. Practical Statistics and Experimental Design for Plant and Crop Science. 1st Edn., John Wiley and Sons, Chichester, ISBN-10: 0471899089, pp: 332.

Hatami, S., A. Nourjou, M. Henareh and L. Pourakbar, 2012. Comparison effects of different methods of black plastic mulching and planting patterns on weed control, water-use efficiency and yield in tomato crops. Int. J. Agric. Sci., 2: 928-934. 
Ibarra, L., J. Flores and J.C. Diaz-Perez, 2001. Growth and yield of muskmelon in response to plastic mulch and row covers. Sci. Hort., 87: 139-145. DOI: 10.1016/S0304-4238(00)00172-2

Igbal, Q., M. Amjad, A. Rafique, A. Asif and R. Ahmad, 2009. Vegetative and reproductive evaluation of hot peppers under different plastic mulches in poly/plastic tunnel. Pak. J. Agric. Sci., 46: 113-118.

Kumar, S.D. and B.R. Lal, 2012. Effect of mulching on crop production under rainfed condition: A review. Int. J. Res. Chem. Environ., 2: 8-20.

Kwabiah, A.B., 2004. Growth and yield of sweet corn (Zea mays L.) cultivars in response to planting date and plastic mulch in a short-season environment. Sci. Hort., 102: 147-166. DOI: 10.1016/j.scienta.2004.01.007

Mamkagh, A.M.A., 2009. Effect of tillage time and black plastic mulch on growth and yield of okra (Abelmoschus esculentus) grown under rain-fed conditions. Int. J. Agric. Biol., 11: 453-457.

Moreno, M.M., A. Moreno and I. Mancebo, 2009. Comparison of different mulch materials in a tomato (Solanum lycopersicum L.) crop. Spanish J. Agric. Res., 7: 454-464. DOI: 10.5424/sjar/2009072-1500

Ogban, P.I., W.N. Ogunewe, R.I. Dike, A.C. Ajaelo and N.I. Ikeata et al., 2008. Effect of tillage and mulching practices on soil properties and growth and yield of cowpea (Vigna unguiculata L. Walp) in southeastern Nigeria. Agro-Sci., 7: 118-128. DOI: 10.4314\%2Fas.v7i2.1593

Parmar, H.N., N.D. Polara and R.R. Viradiya, 2013. Effect of mulching material on growth, yield and quality of watermelon (Citrullus lanatus thunb) $\mathrm{Cv}$. Kiran. Univ. J. Agric. Res., 1: 30-37. DOI: 10.13189/ujar.2013.010203
Pawar, S.N., S.P. Divekar, S.B. Ghule and A.S. Kadale, 2004. Effect of mulching on moisture conservation and yield of summer groundnut. J. Soil Crops, 14: 410-413.

Ramakrishna, A., M.T. Hoang, P.W. Suhas and D.L. Tranh, 2006. Effect of mulch on soil temperature, moisture, weed infestation and yield of groundnut in northern Vietnam. Field Crops Res., 95: 115-125. DOI: 10.1016/j.fcr.2005.01.030

Rashidi, M., M. Gholam and S. Abbass, 2010. Effect of plastic mulch and tillage method on yield and yield components of tomato (Lycopersicon esculentum). J. Agric. Biol. Sci., 5: 5-11.

Sharma, P.K., P.C. Kharwara and R.K. Tewatia, 1990. Residual soil moisture and wheat yield in relation to mulching and tillage during preceding rainfed crop. Soil Till. Res., 15: 279-284. DOI: 10.1016/01671987(90)90084-Q

Singh, A.K. and S. Kamal, 2012. Effect of black plastic mulch on soil temperature and tomato yield in mid hills of Garhwal Himalayas. J. Hort. Forest., 4: 7880. DOI: $10.5897 / \mathrm{JHF} 11.023$,

Tisdall, J.A., R.D. Baverly and D.E. Radcliffe, 1991. Mulch effect on soil properties and tomato growth using micro-irrigation. Agron. J., 83: 1028-1034. DOI: 10.2134/agronj1991.00021962008300060019x

Wang, Y., Z. Xie, S. Malhi, C. Vera and Y. Zhang et al., 2009. Effects of rainfall harvesting and mulching technologies on water use efficiency and crop yield in the semi-arid Loess Plateau, China. Agric. Water Manage., 96: 374-382. DOI: 10.1016/j.agwat.2008.09.012

Wilkinson, L., 1990. SYSTAT: The System for Statistics for the PC. 1st Edn., SYSTAT, ISBN-10: 0928789071, pp: 822. 